\title{
Hyperthermophilic Composting Technology for Organic Solid Waste Treatment: Recent Research Advances and Trends
}

\author{
Shaofeng Wang ${ }^{1}$ and Yuqi $\mathrm{Wu}^{2, *}$ \\ 1 School of Civil Engineering, Lanzhou University of Technology, Lanzhou 730050, China; scuwsf@163.com \\ 2 College of Environmental Science and Engineering, Taiyuan University of Technology, Taiyuan 030024, China \\ * Correspondence: wuyuqi@tyut.edu.cn
}

check for updates

Citation: Wang, S.; Wu, Y. Hyperthermophilic Composting Technology for Organic Solid Waste Treatment: Recent Research Advances and Trends. Processes 2021, 9, 675. https://doi.org/10.3390/pr9040675

Academic Editor: Sharif Zein

Received: 7 March 2021

Accepted: 12 April 2021

Published: 13 April 2021

Publisher's Note: MDPI stays neutral with regard to jurisdictional claims in published maps and institutional affiliations.

Copyright: (c) 2021 by the authors. Licensee MDPI, Basel, Switzerland. This article is an open access article distributed under the terms and conditions of the Creative Commons Attribution (CC BY) license (https:// creativecommons.org/licenses/by/ $4.0 /)$.

\begin{abstract}
Organic solid waste is considered a renewable resource that can be converted by various technologies into valuable products. Conventional thermophilic composting (TC), a well-studied and mature technology, can be applied to organic solid waste treatment to achieve waste reduction, mineralization, and humification simultaneously. However, poor efficiency, a long processing period, as well as low compost quality have always limited its wide application. In order to overcome these shortages, hyperthermophilic composting (HTC) has been recently put forward. This paper reviews the basic principle, process flow, operation parameters, research advances, and application status of HTC. Compared with the TC process, the shorter composting period and higher temperature and treatment efficiency, as well as more desirable compost quality, can be achieved during HTC by inoculating the waste with hyperthermophilic microbes. Additionally, HTC can reduce greenhouse gas emission, increase the removal rate of microplastics and antibiotic residues, and achieve insitu remediation of heavy metal-polluted soils, which greatly improve its application potential for organic solid waste treatment. This paper also proposes the limitations and future prospects of HTC technology for a wider application. As a result, this review advances our understanding of the HTC process, which promotes its further investigation and application.
\end{abstract}

Keywords: organic solid waste; hyperthermophilic composting; hyperthermophilic microbes; composts; humification

\section{Introduction}

With rapid population growth and urbanization development worldwide, large amounts of organic solid waste are produced every day, the efficient treatment and disposal of which have become one of the most significant issues for many countries. Organic solid waste mainly consists of sewage sludge, food waste, aquacultural waste, agricultural waste, and livestock manure [1-3] (Figure 1), the composition of which, in different countries and areas, heavily depends upon population size and economic development levels [4]. Globally, existing wastewater treatment plants in the USA and Japan generated 6.5 and 2 million tons of dry sewage sludge in 2015, respectively [5], and 33.3\% of food produced worldwide becomes food waste, i.e., an annual loss of about 1.6 billion tons of food [6,7]. The annual production of livestock manure in 27 European member states is approximately 1.4 billion tons, and, in the USA, above 1 billion tons of livestock manure is produced per year [8]. In China, the production of sewage sludge with $80 \%$ water content exceeded 55 million tons in 2015; approximately 3.8 billion tons of livestock manure, 4.9 million tons of fish processing waste, 180 to 270 million tons of rice straw, and 97.72 million tons of food waste are produced annually [9-11]. Moreover, the yield of organic solid waste has been on an upward trend due to economic development and population increase [12-14]. 


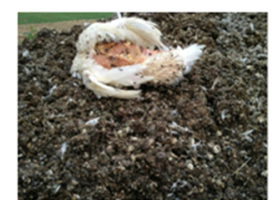

Livestock manure

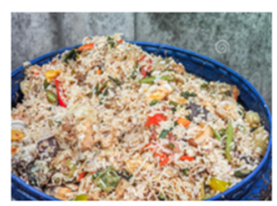

Food waste

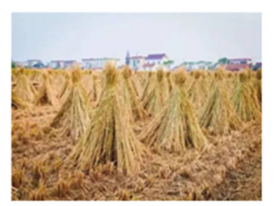

Agricultural waste

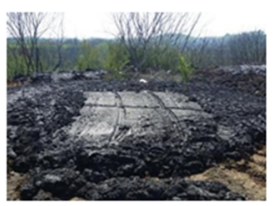

Sewage sludge

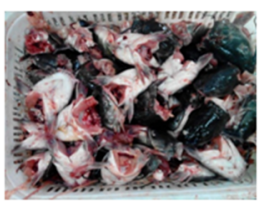

Aquacultural waste

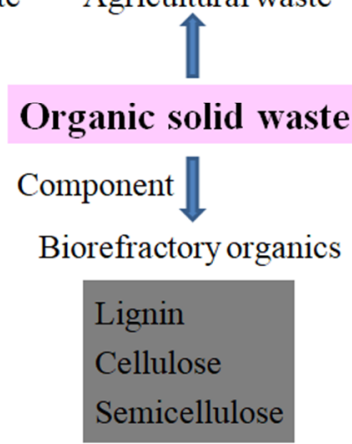

Toxic substances

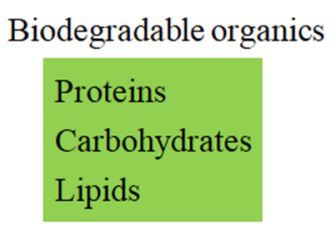

Figure 1. The categories and components of organic solid waste (images by Yuqi Wu).

Indeed, organic solid waste is rich in biodegradable organic matter (e.g., proteins, carbohydrates, and lipids) and plant nutrients (nitrogen, phosphorus, and potassium), which can be considered low-cost and easily available feedstock for resource recycling $[6,15,16]$. However, it also contains a myriad of biorefractory organic matter, such as lignin, cellulose, and semicellulose, as well as toxic substances, including pathogens, heavy metals, antibiotic residues, and the associated resistance genes and pesticide residues, as shown in Figure $1[5,17,18]$. Therefore, the management of organic solid waste is complex given that its heterogeneity, instability, and potential toxicity. If improperly treated, it can contribute to soil, water, and air pollution, threaten human health, and even cause ecological imbalance.

In recent years, some researchers have been devoted to exploring high-efficiency technologies for organic solid waste management that can achieve environmental sustainability and economic viability simultaneously. Landfill, incineration, anaerobic digestion, and thermophilic composting (TC) are widely implemented technologies for organic solid waste treatment [1,19-21]. However, these technologies have various limitations, such as high cost, large land footprint, high process complexity, posthandling of residues, and secondary pollution $[22,23]$. As a newly-developed technology for organic solid waste management, hyperthermophilic composting (HTC) has attracted much attention due to its unique advantages, which include high efficiency, convenient process, and little posthandling of residues [24,25]; recently, some research papers have been published on HTC performance and its mechanisms [26-28].

To the best of our knowledge, few published papers have done a comprehensive review on HTC based on the latest research results. In this instance, this study attempts to compare HTC with conventional technologies for organic solid waste management and offer a critical review and comprehensive analysis of HTC, according to the latest research findings. In addition, some full-scale demonstration projects of HTC are presented in the current study.

\section{Classical Organic Solid Waste Treatment Technologies}

Several conventional technologies have been widely utilized for organic solid waste treatment and disposal, including landfill, incineration, anaerobic digestion, and thermophilic composting, as shown in Figure 2. 


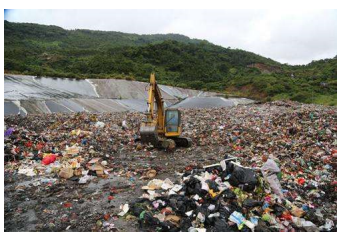

(A)

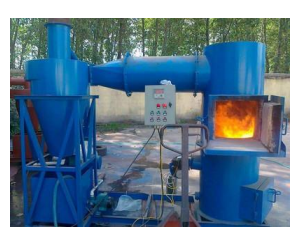

(B)

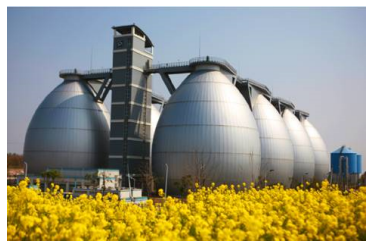

(C)

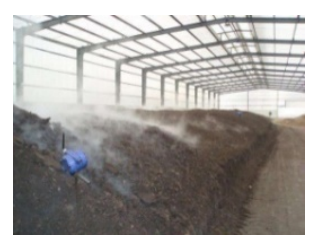

(D)

Figure 2. Conventional technologies for organic solid waste treatment. (A) Landfill; (B) incineration; (C) anaerobic digestion; (D) thermophilic composting [29].

Landfill is the oldest technology for solid waste management, in which various organic solid wastes are mixed, compressed, dewatered, and dumped into natural or artificial pits, and then degraded by different microbes. The advantages of this technology included easy operation and management, low costs, and large treatment capacity [30,31]. However, large land occupation, leachate with heavy metals, ammonia, and refractory organics, greenhouse gas (GHG) emission (mainly including methane and carbon dioxide), and poor sanitation have limited its wide application [32,33]. In recent years, landfills have been gradually forbidden in more and more countries and areas, considering the above disadvantages $[6,34,35]$.

Incineration is one of the most common technologies used to treat solid waste around the world. Mixed organic solid waste is burned at $800-1000{ }^{\circ} \mathrm{C}$ with additional fuels, which can achieve the total killing of pathogens, more than $90 \%$ of volume reduction, as well as electricity and heat energy recovery [36]. However, this technology is not environmentally friendly or sustainably developed in view of some remarkable disadvantages, including high cost and energy demand, GHG and harmful gas (such as dioxins and sulfur dioxide) emission, and production of residual ashes rich in heavy metals [37-39]. Therefore, incineration-based organic solid waste treatment technology might be challenged worldwide.

Anaerobic digestion (AD) has been widely applied for various organic solid waste treatments that can achieve methane recycle, volume reduction, organic degradation, and pathogen inactivation simultaneously [40]. Additionally, AD has shown less influence on air quality than other technologies and is conducive to minimizing carbon emission [41]. Single or mixed organic solid waste can act as a substrate for anaerobic digestion [42,43]; thousands of related studies have been published [44-46]. However, it is worth noting that some digestates rich in heavy metals, microplastics (MPs), and antibiotic resistance genes (ARGs) cannot be directly used for agriculture or forestry and should be further disposed of by other methods [47-49]. In addition, high cost, process complexity, and a significant loss of plant nutrients also need to be addressed.

Thermophilic composting is a convenient and long-standing biological technology conducted under aerobic conditions; it transforms organic solid waste into agricultural resources, i.e., organic fertilizer or soil amendment, and is able to achieve pathogen inactivation and waste volume reduction [50,51]. Compared with other conventional technologies, TC has the advantages of low cost, easy operation, and less solid residues [52,53], and numerous full-scale TC projects for organic solid waste treatment have been implemented worldwide. For example, TC is widely used for the treatment of organic waste from chicken production chains in Brazil [54]. However, it is worth noting that long processing periods, low quality of composts, large nitrogen loss, GHG and various organic sulfur compound emissions, limited pathogen inactivation efficiency, as well as poor sanitation have become bottlenecks for TC $[23,55,56]$, all of which are largely attributed to limited temperature and the thermal intolerance of the native microbes [57]. It seems that TC cannot act as a feasible solution for organic solid waste management in high urbanized areas and cities. 


\section{Hyperthermophilic Composting Mechanisms}

\subsection{Comparison between Hyperthermophilic Composting and Thermophilic Composting}

The feature comparison between HTC and TC is shown in Table 1. Among these parameters, temperature is one of the most significant parameters during the composting process; it should be monitored throughout the process [58]. For the conventional TC process, the maximum temperature ranges from 50 to $70^{\circ} \mathrm{C}$, which limits the performance of organic decomposition, pathogen inactivation, as well as humification degree. By inoculating the waste with hyperthermophilic microbes, the maximum temperature during the composting process can exceed $80^{\circ} \mathrm{C}$ and last for 5-7 days without an external thermal source because of the process called HTC. There were four stages during HTC: the temperature rising stage, the hyperthermophilic phase, the thermophilic phase and the maturation stage. Due to the development of a hyperthermophilic microbial community during HTC, this can lead to an improvement in organic biodegradation efficiency, composting efficiency, and sanitation situations. In addition, pathogen killing efficiency is enhanced in HTC due to the extremely high temperature. For the same reason, nitrification and denitrification processes can hardly take place, and organic nitrogen is either converted to ammonium or an undigested form, leading to less loss of nitrogen [59]. In addition, the initial C/N ratio is also a critical parameter to enhance microbial activity and optimize the composting process; the germination index (GI), a commonly used variable to evaluate the maturity of composts, is shown in Table 1.

Table 1. Feature comparison of hyperthermophilic composting (HTC) and thermophilic composting (TC) for organic solid waste treatment.

\begin{tabular}{cccc}
\hline Characteristic & HTC & TC & Ref. \\
\hline Maximum temperature $\left({ }^{\circ} \mathrm{C}\right)$ & $>80$ & $50-70$ & {$[59,60]$} \\
Average temperature $\left({ }^{\circ} \mathrm{C}\right)$ & 70 & 40 & {$[59,60]$} \\
Thermophilic period $(\mathrm{d})$ & $\geq 80{ }^{\circ} \mathrm{C}, 5-7 \mathrm{~d}$ & $\geq 50{ }^{\circ} \mathrm{C}, 5-7 \mathrm{~d}$ & {$[60]$} \\
Composting period $(\mathrm{d})$ & $15-25$ & $30-50$ & {$[60]$} \\
Low C/N $(<10)$ for start-up & Easy & Hard & {$[57]$} \\
Compost maturity & GI a $\geq 95 \%$ & GI $\geq 65 \%$ & {$[60]$} \\
Pathogens inactivation rate & High & Low & {$[60]$} \\
Waste weight reduction $(\%)$ & 52.4 & 45.9 & {$[57]$} \\
Moisture loss $(\%)$ & 58.9 & 53.4 & {$[57]$} \\
Organic matter loss $(\%)$ & 66.8 & 63.8 & {$[57]$} \\
Nitrogen loss $(\%)$ & 26.2 & 31.0 & {$[57]$} \\
Odor & 26.1 & 44.2 & {$[27]$} \\
Operation cost & $\mathrm{NH}_{3}$, less & $\mathrm{NH}_{3}, \mathrm{H}_{2} \mathrm{~S}, \mathrm{SO} \mathrm{O}_{2}$, more & {$[60]$} \\
\hline L & Low & $\mathrm{High}^{2}$ & {$[57]$} \\
\hline
\end{tabular}

a Germination index.

\subsection{Hyperthermophilic Inoculants and Microbial Community Structure}

Hyperthermophilic microbes act as promoters during HTC, which can promote organic solid waste mineralization and humification and release thermal energy through their metabolism. Many researchers have been dedicated to exploring hyperthermophilic inoculants, and some inoculants have been available for many years. YM bacteria, belonging to Bacillus, was discovered by Yamamura Masaichi and has obtained patent certification in China (No. ZL 02826097. X) and been applied to a large-scale HTC plant for sewage sludge treatment [61]. According to the study [61], the mixture ratio of solid YM bacteria and sewage sludge is about 2 on the basis of weight. Liquid hyperthermophilic inoculants produced by GeoGreen Innotech Co. Ltd., Beijing, China, have been utilized for various organic solid waste treatments in full-scale HTC plants [60]. In the study of Cui et al. [27,62], $0.5 \%$ liquid inoculants, on the basis of weight, were mixed with chicken manure and rice husks; desirable composting performances were achieved. In addition, DY bacteria, discovered by Tong Zhu from Northeastern University in China, has been utilized in some 
full-scale HTC projects and can promote humification remarkably (information obtained from communication with engineers and internet communities [63]).

The microbial community of HTC is heterogeneous and differs from one locality or phase to another; it is based on multiple interactions and interdependencies among the participating species and organisms [64]. Recently, the microbial community structure associated with HTC has been deeply investigated by means of modern microbiological technology to reveal the composting mechanisms. The family Thermaceae, belonging to the Deinococcus-Thermus phylum, which is able to survive under hyperthermophilic conditions, is predominant during the hyperthermophilic and thermophilic phases. As a result, Thermus within the family Thermaceae has been found as the dominant community; it can produce large quantities of enzymes, e.g., hydrolytic enzymes and catalases, which can adapt to extremely high temperatures and exceed the upper growth limit of most microbes. Another dominant family during the thermophilic phase is Thermoactinomycetaceae, which can produce large amounts of dehydrogenase, polyphenol oxidase, and urease. Planifilum, a thermophilic genus belonging to Thermoactinomycetaceae, is another predominant genus during the thermophilic phase. The families Bacillaceae and Sulfobacillaceae have also been detected frequently during the HTC process. During the maturation phase, the genus Actinomadura within Thermomonosporaceae and Sphingobacterium within Sphingobacteriaceae have been found as the predominant communities [58].

\subsection{Operation Parameters and Process Flow}

The performance of HTC is affected by initial water content, $\mathrm{pH}, \mathrm{C} / \mathrm{N}$, organic composition, mechanical aeration rates, artificial turning rates, and temperature, among which initial water content and $\mathrm{C} / \mathrm{N}$ of organic solid waste and mechanical aeration rate are the most important parameters $[65,66]$. According to previous studies, the optimal operation parameters for HTC include an initial C/N of 10 , an initial water content of $50 \%$, and a mechanical aeration rate of $20 \mathrm{~m}^{3} /(\mathrm{t} \cdot \mathrm{h})$ [60].

The process flow of HTC is illustrated in Figure 3. Firstly, a single type or a mixture of organic solid waste is pretreated to adjust the initial water content and $\mathrm{C} / \mathrm{N}$, and then hyperthermophilic inoculants are added. In the composting tank, mechanical aeration and artificial turning are conducted periodically, and organic mineralization and humification can be achieved through the hyperthermophilic microbes' metabolism. During the composting process, gases, including $\mathrm{N}_{2} \mathrm{O}, \mathrm{CO}_{2}$, and $\mathrm{NH}_{3}$, are collected in order to avoid secondary pollution to the environment. At the end of composting, the final product (compost) is collected and then further processed into humus, acting as agricultural fertilizer, and part of the compost is recycled to act as the inoculant.

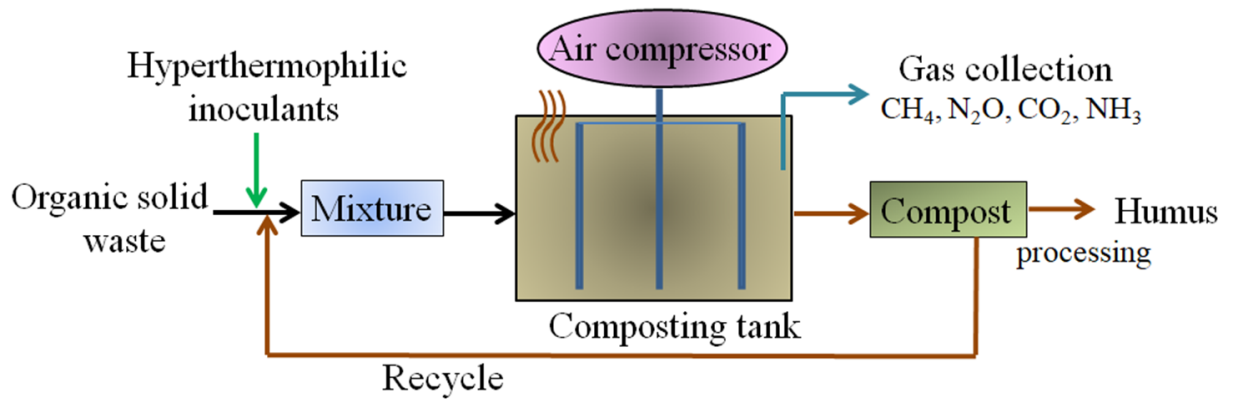

Figure 3. Schematic diagram of hyperthermophilic composting.

\section{Hyperthermophilic Composting Research and Application}

\subsection{Compost Formation from Various Organic Solid Wastes}

In China, several large-scale HTC plants have been built and operating steadily for many years; their process flow is shown in Figure 4. For example, there is an HTC plant for sewage sludge treatment located in Beijing, China, of which the daily processing capacity is $600 \mathrm{t}$; after 15-20 days of composting, the final product can be applied as soil amendment 
in gardens. In 2013, a full-scale HTC project for cattle manure treatment was carried out in Jaozuo, China, where $40 \mathrm{t}$ cattle manure can be treated and $10 \mathrm{t}$ of superior compost is produced daily. Moreover, the average temperature during the cattle manure HTC process is above $80{ }^{\circ} \mathrm{C}$, and very little odor and leachate are released throughout the process [60]. However, the treatment capacity of this cattle manure HTC process needs to be further improved.

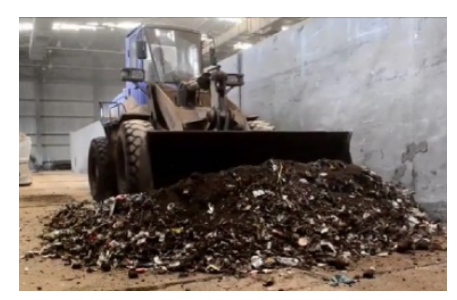

(A)

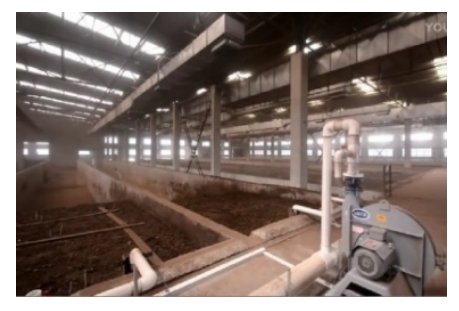

(B)

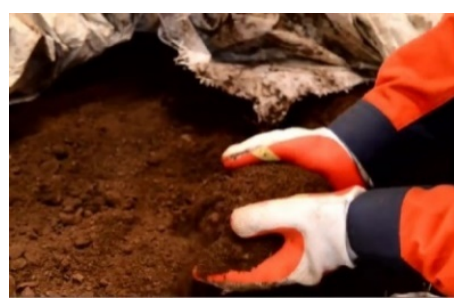

(C)

Figure 4. Photograph of the full-scale hyperthermophilic composting process. (A) Mixture of inoculants and organic solid waste; (B) composting; (C) mature compost [67].

\subsection{Decreasing Greenhouse Gas Emission}

Large amounts of anthropogenic GHG emission are a serious issue for conventional $\mathrm{TC}$, especially nitrous oxide $\left(\mathrm{N}_{2} \mathrm{O}\right)$. The microbial-participated denitrification process is regarded as the most important source of $\mathrm{N}_{2} \mathrm{O}$ emission in the composting system. $\mathrm{N}_{2} \mathrm{O}$ contributes about 300 times more to global warming potential than an equivalent mass of $\mathrm{CO}_{2}$. During the HTC process, a reduction in $\mathrm{N}_{2} \mathrm{O}$ emission of up to $90 \%$ was achieved compared to TC in a full-scale plant in the study of Cui et al. [62]. Mechanism analysis indicated that the nitrification rate and the $\mathrm{N}_{2} \mathrm{O}$ formation rate decreased due to inhibition of the abundance of bacterial $a m o A$ and nor $B$ genes under extremely high temperature conditions during $\mathrm{HTC} ; \mathrm{NO}_{2}{ }^{-}-\mathrm{N}$ and $\mathrm{NO}_{3}{ }^{-}-\mathrm{N}$ levels decreased, leading to $\mathrm{N}_{2} \mathrm{O}$ emission decreasing. Additionally, statistical analysis indicated that the extremely high temperature was the primary reason for lower $\mathrm{N}_{2} \mathrm{O}$ emissions in $\mathrm{HTC}$, and physicochemical characteristics in TC, including water content, $\mathrm{pH}$, electrical conductivity, $\mathrm{NH}_{4}{ }^{+}-\mathrm{N}$, and total nitrogen, were the main factors for higher $\mathrm{N}_{2} \mathrm{O}$ production.

\subsection{In Situ Biodegradation of Microplastics}

Microplastics (MPs) have attracted much attention in recent years due to the potential threat to the ecological environment and human and animal health. Organic solid waste derived from aquatic and terrestrial environments contains large amounts of MPs. Land application as fertilizer or soil amendment is the conventional method for organic waste management that might introduce large amounts of organic solid-waste-based MPs to the soil. Therefore, it is time to put forward an efficient technology to treat organic solid-waste-based MPs. Chen et al. [68] conducted a full-scale HTC process to treat sewagesludge-based MPs, and $43.7 \%$ of the MPs were in-situ removed after 45 days of operation. The mechanism analysis was conducted through a bench-scale HTC experiment using HTC inoculum with a polystyrene-microplastic (PS-MP) addition. The results showed that $7.3 \%$ of PS-MPs could be degraded at $70{ }^{\circ} \mathrm{C}$ in 56 days, a more than 6.6 -fold increase compared to TC. During the HTC process, hyperthermophilic bacteria, mainly including Thermus, Bacillus, and Geobacillus, make a great contribution to PS-MP biodegradation due to efficient bio-oxidation and biodegradation effects.

\subsection{Remediation of Heavy-Metal-Polluted Soils}

Traditionally, large amounts of organic solid waste are disposed of in landfills, although this process always causes serious environmental pollution through leachates, among which heavy metals are a serious threat to the surrounding environment. Developing efficient technologies to treat organic solid waste and alleviate heavy metal pollution 
simultaneously has attracted much attention recently. In the study of Tang et al. [69], Cu(II), acting as a representative heavy metal, was utilized to investigate the complexation of $\mathrm{Cu}$ (II) to humic acids (HAs) derived from HTC, TC, and raw sewage sludge. Results showed that the order of complexation ability, from high to low, was HTC-derived HAs, TC-derived HAs, and sewage sludge-derived HAs, which was attributed to a higher humification degree and the faster response of carboxyl and phenols to $\mathrm{Cu}$ (II)-binding with HAs from HTC. Therefore, compared to TC and sewage sludge, HTC is more efficient in $\mathrm{Cu}(\mathrm{II})$-polluted soil remediation.

In the study of Chen et al. [70], Thermus thermophilus (T. thermophilus) FAFU013 was inoculated to HTC of $\mathrm{Pb}$ (II)-polluted solid biowaste. After 40 days of HTC with T. thermophilus FAFU013 inoculation, the most insoluble residual fractions of $\mathrm{Pb}$ increased by $16.0 \%$ (from $76.5 \%$ to $92.5 \%$ ), which was approximately 3 times higher than that of the TC group; this indicated a remarkable $\mathrm{Pb}$ passivation by the hyperthermophilic microbes.

\subsection{Removal of Antibiotic Residues and Antibiotic Resistance Genes}

The threat of antibiotic residues to the natural environment has become a critical worldwide issue in recent years. Researchers have been devoted to developing effective methods to treat organic waste with antibiotic residues and antibiotic resistance genes (ARGs) to alleviate environmental pollution. HTC has been proven to be an efficient technology to achieve the reduction of antibiotic residues and ARGs from organic solid waste. For example, HTC effectively removed $95.0 \%$ of tylosin antibiotic fermentation residues and $75.8 \%$ of related ARGs; these results were attributed to a decrease in the abundance of antibiotic resistance plasmids and related host bacteria [71]. In the study of Liao et al. [72], HTC and TC were conducted to evaluate the removal efficiency of ARGs and mobile genetic elements (MGEs), and the related mechanisms were investigated. The results showed that the removal rate of ARGs and MGEs during HTC was 89\%, which was much higher than that during TC (49\%). The mechanism analysis indicated that the stability of ARGs and MGEs were negatively affected by the extremely high temperature, and MGE reduction played a vital role in ARG removal in HTC.

\section{Implication and Future Perspectives}

Based on the above analysis, it is indicated that HTC shows remarkable advantages over conventional technologies for organic solid waste treatment, including easy operation, resource recycling, little residue and odor emission, and a short processing period. In particular, HTC can effectively decrease GHG emission, in situ degrade MPs, remediate $\mathrm{Cu}(\mathrm{II}) / \mathrm{Pb}$ (II)-polluted soils, and remove antibiotic residues and ARGs, the results of which are far superior to conventional TC, as shown in Figure 5. However, there are still some problems that need to be addressed before HTC's wide application. Firstly, HTC has been applied to sewage sludge, livestock manure, and agricultural waste treatment; however, studies on its application to food waste and aquacultural waste management are scarce. It was well known that lipids, oils, or salinity-rich solid waste as composting substrates can cause system instability [6]; this needs further investigation. Secondly, organic mineralization is accelerated during the HTC process, while the organic content in the composts inevitably decreases, leading to fertilizer efficiency loss. In this situation, it is crucial to keep the balance between composting efficiency and compost nutrients [61]. Thirdly, the performances of other heavy metal ( $\mathrm{Zn}, \mathrm{Cd}, \mathrm{Cr}, \mathrm{Ni}$, and As)-polluted soil remediation during the HTC process should be further investigated. Fourthly, the safety of hyperthermophilic microbes with regards to humans, animals, and agricultural plants should be verified. Moreover, technoeconomic analysis is essential for a novel technology before large-scale application. 


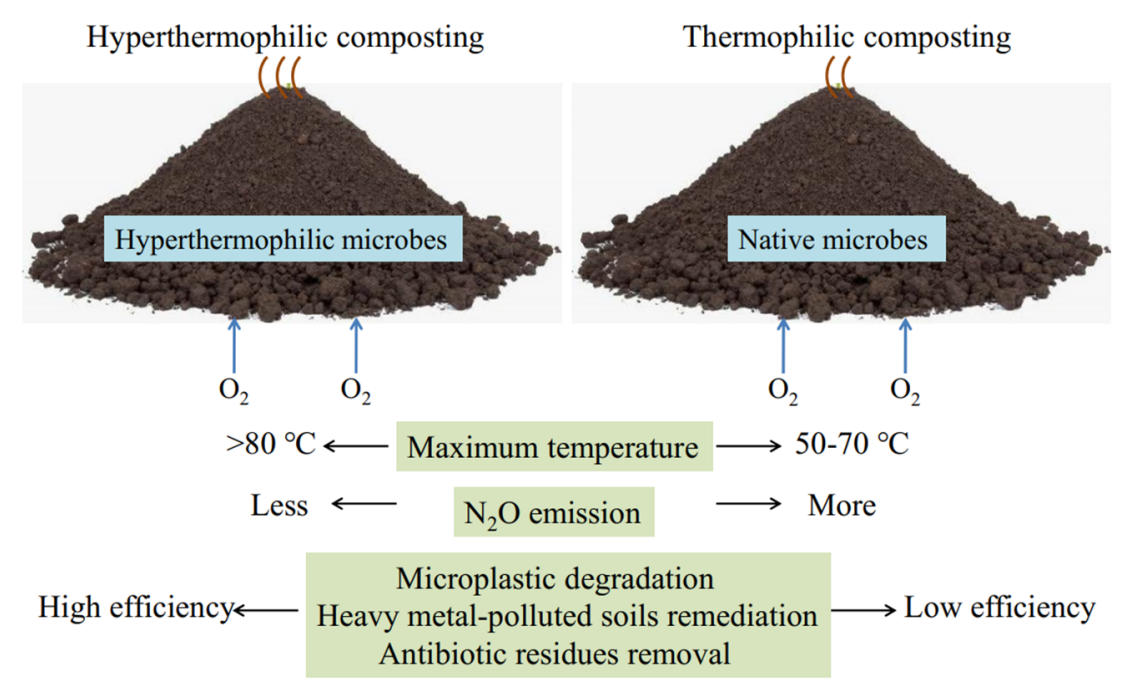

Figure 5. Comparison of operation conditions and performances between HTC and TC.

\section{Conclusions}

Organic solid waste is rich in biodegradable organics and plant nutrients, which can serve as potential feedstock for composting. This review offers a comprehensive analysis of the newly-developed hyperthermophilic composting. Compared with conventional technologies for organic solid waste management, HTC has the advantages of low cost, easy operation, little residue and odor emission, and high efficiency, and its final product can act as a desirable agricultural resource. More importantly, HTC showed better performance on reduction of GHG emissions, remediation of heavy metal-polluted soils, and removal of MPs and antibiotic residues compared to TC; this has attracted much attention. Further studies focusing on lipid- and salinity-rich waste management and retaining higher fertilizer efficiency in the composts are needed to further improve the superiority of HTC.

Author Contributions: Conceptualization and writing-original draft preparation, Y.W.; writingreview and editing, S.W. Both authors have read and agreed to the published version of the manuscript.

Funding: This research was supported by the Ministry of Environmental Protection of the People's Republic of China (Major Science and Technology Program, Nos. 2019YFC0408601 and 2019YFC0408602), the National Natural Science Foundation of China (NSFC, No. 52070139), and the Key Research and Development (R\&D) Project of Shanxi Province (Nos. 201903D321057 and 201903D321055).

Institutional Review Board Statement: Not applicable.

Informed Consent Statement: Not applicable.

Data Availability Statement: The data presented in this study are available on request from the corresponding author.

Conflicts of Interest: The authors declare no conflict of interest.

\section{References}

1. Wainaina, S.; Awasthi, M.K.; Sarsaiya, S.; Chen, H.Y.; Singh, E.; Kumar, A.; Ravindran, B.; Awasthi, S.K.; Liua, T.; Duan, Y.M.; et al. Resource Recovery and Circular Economy from Organic Solid Waste Using Aerobic and Anaerobic Digestion Technologies. Bioresour. Technol. 2020, 301, 122778. [CrossRef]

2. Soobhany, N. Insight into the Recovery of Nutrients from Organic Solid Waste through Biochemical Conversion Processes for Fertilizer Production: A review. J. Clean. Prod. 2019, 241, 118413. [CrossRef]

3. Peng, W.; Pivato, A. Sustainable Management of Digestate from the Organic Fraction of Municipal Solid Waste and Food Waste Under the Concepts of Back to Earth Alternatives and Circular Economy. Waste Biomass Valor. 2019, 10, 465-481. [CrossRef]

4. Speier, C.J.; Mondal, M.M.; Weichgrebe, D. Evaluation of Compositional Characteristics of Organic Waste Shares in Municipal Solid Waste in Fast-growing Metropolitan Cities of India. J. Mater. Cycles Waste 2018, 20, 2150-2162. [CrossRef] 
5. Zhen, G.Y.; Lu, X.Q.; Kato, H.; Zhao, Y.C.; Li, Y.Y. Overview of Pretreatment Strategies for Enhancing Sewage Sludge Disintegration and Subsequent Anaerobic Digestion: Current Advances, Full-scale Application and Future Perspectives. Renew. Sust. Energy Rev. 2017, 69, 559-577. [CrossRef]

6. Ma, Y.Q.; Liu, Y. Turning Food Waste to Energy and Resources towards a Great Environmental and Economic Sustainability: An Innovative Integrated Biological Approach. Biotechnol. Adv. 2019, 37, 107414. [CrossRef] [PubMed]

7. Kumar, A.; Samadder, S.R. Performance Evaluation of Anaerobic Digestion Technology for Energy Recovery from Organic Fraction of Municipal Solid Waste: A Review. Energy 2020, 197, 117253. [CrossRef]

8. Gurmessa, B.; Pedretti, E.F.; Cocco, S.; Cardelli, V.; Corti, G. Manure Anaerobic Digestion Effects and the Role of Pre- and Post-treatments on Veterinary Antibiotics and Antibiotic Resistance Genes Removal Efficiency. Sci. Total Environ. 2020, 721, 137532. [CrossRef]

9. Zhao, X.F.; Li, L.; Wu, D.; Xiao, T.H.; Ma, Y.; Peng, X.Y. Modified Anaerobic Digestion Model No. 1 for Modeling Methane Production from Food Waste in Batch and Semi-continuous Anaerobic Digestions. Bioresour. Technol. 2019, 271, 109-117. [CrossRef]

10. Choe, U.; Mustafa, A.M.; Lin, H.J.; Xu, J.; Sheng, K.C. Effect of Bamboo Hydrochar on Anaerobic Digestion of Fish Processing Waste for Biogas Production. Bioresour. Technol. 2019, 283, 340-349. [CrossRef]

11. Li, Y.; Chen, Y.G.; Wu, J. Enhancement of Methane Production in Anaerobic Digestion Process: A review. Appl. Energy 2019, 240, 120-137. [CrossRef]

12. Sarpong, D.; Oduro-Kwarteng, S.; Gyasi, S.F.; Buamah, R.; Donkor, E.; Awuah, E.; Baah, M.K. Biodegradation by Composting of Municipal Organic Solid Waste into Organic Fertilizer Using the Black Soldier Fly (Hermetia illucens) (Diptera: Stratiomyidae) Larvae. Int. J. Recycl. Org. Waste Agric. 2019, 8, S45-S54. [CrossRef]

13. Salehiyoun, A.R.; Sharif, M.; Maria, F.D.; Zilouei, H.; Aghbashlo, M. Effect of Substituting Organic Fraction of Municipal Solid Waste with Fruit and Vegetable Wastes on Anaerobic Digestion. J. Mater. Cycles Waste 2019, 21, 1321-1331. [CrossRef]

14. Ossa-Arias, M.M.; González-Martínez, S. Methane Production from the Organic Fraction of Municipal Solid Waste Under Psychrophilic, Mesophilic, and Thermophilic Temperatures at Different Organic Loading Rates. Waste Biomass Valor. 2021. [CrossRef]

15. Khiari, Z.; Kaluthota, S.; Savidov, N. Aerobic Bioconversion of Aquaculture Solid Waste into Liquid Fertilizer: Effects of Bioprocess Parameters on Kinetics of Nitrogen Mineralization. Aquaculture 2019, 500, 492-499. [CrossRef]

16. Mo, W.Y.; Man, Y.B.; Wong, M.H. Use of Food Waste, Fish Waste and Food Processing Waste for China's Aquaculture Industry: Needs and Challenge. Sci. Total Environ. 2018, 613-614, 635-643. [CrossRef] [PubMed]

17. Zhi, S.L.; Li, Q.; Yang, F.X.; Yang, Z.J.; Zhang, K.Q. How Methane Yield, Crucial Parameters and Microbial Communities Respond to the Stimulating Effect of Antibiotics During High Solid Anaerobic Digestion. Bioresour. Technol. 2019, 283, 286-296. [CrossRef] [PubMed]

18. Pleissner, D.; Peinemann, J.C. The Challenges of Using Organic Municipal Solid Waste as Source of Secondary Raw Materials. Waste Biomass Valor. 2020, 11, 435-446. [CrossRef]

19. De la Cruz, F.B.; Cheng, Q.W.; Call, D.F.; Barlaz, M.A. Evidence of Thermophilic Waste Decomposition at a Landfill Exhibiting Elevated Temperature Regions. Waste Manag. 2021, 124, 26-35. [CrossRef]

20. Tyagi, V.K.; Bhatia, A.; Kubota, K.; Rajpal, A.; Ahmed, B.; Khan, A.A.; Kazmi, A.A.; Kumar, M. Microbial Community Dynamics in Anaerobic Digest. Environ. Technol. Innov. 2021, 21, 101303. [CrossRef]

21. Vlaskin, M.S.; Vladimirov, G.N. Hydrothermal Carbonization of Organic Components from Municipal Solid Waste. Theor. Found. Chem. Eng. 2018, 52, 996-1003. [CrossRef]

22. Elalami, D.; Carrere, H.; Monlau, F.; Abdelouahdi, K.; Oukarroum, A.; Barakat, A. Pretreatment and Co-digestion of Wastewater Sludge for Biogas Production: Recent Research Advances and Trends. Renew. Sustain. Energy Rev. 2019, 114, 109287. [CrossRef]

23. Huang, Y.; Dan, Y.L.; Shah, G.M.; Chen, W.; Wang, W.; Xu, Y.D.; Huang, H.Y. Hyperthermophilic Pretreatment Composting Significantly Accelerates Humic Substances Formation by Regulating Precursors Production and Microbial Communities. Waste Manag. 2019, 92, 89-96. [CrossRef] [PubMed]

24. Yu, Z.; Liu, X.M.; Chen, C.Y.; Liao, H.P.; Chen, Z.; Zhou, S.G. Molecular Insights into the Transformation of Dissolved Organic Matter during Hyperthermophilic Composting using ESI FT-ICR MS. Bioresour. Technol. 2019, 292, 122007. [CrossRef] [PubMed]

25. Yu, Z.; Liu, X.M.; Zhao, M.H.; Zhao, W.Q.; Liu, J.; Tang, J.; Liao, H.P.; Chen, Z.; Zhou, S.G. Hyperthermophilic Composting Accelerates the Humification Process of Sewage Sludge: Molecular Characterization of Dissolved Organic Matter Using EEMPARAFAC and Two-dimensional Correlation Spectroscopy. Bioresour. Technol. 2019, 274, 198-206. [CrossRef] [PubMed]

26. Liu, X.M.; Hou, Y.; Li, Z.; Yu, Z.; Tang, J.; Wang, Y.Q.; Zhou, S.G. Hyperthermophilic Composting of Sewage Sludge Accelerates Humic Acid Formation: Elemental and Spectroscopic Evidence. Waste Manag. 2020, 103, 342-351. [CrossRef] [PubMed]

27. Cui, P.; Liao, H.P.; Bai, Y.D.; Li, X.; Zhao, Q.; Chen, Z.; Yu, Z.; Yi, Z.G.; Zhou, S.G. Hyperthermophilic Composting Reduces Nitrogen Loss via Inhibiting Ammonifiers and Enhancing Nitrogenous Humic Substance Formation. Sci. Total Environ. 2019, 692, 98-106. [CrossRef]

28. Huang, W.F.; Li, Y.M.; Liu, X.M.; Wang, W.W.; Wen, P.; Yu, Z.; Zhou, S.G. Linking the Electron Transfer Capacity with the Compositional Characteristics of Dissolved Organic Matter during Hyperthermophilic Composting. Sci. Total Environ. 2021, 755, 142687. [CrossRef]

29. Photographs. Available online: https://image.baidu.com/ (accessed on 1 June 2020). 
30. Kim, Y.M.; Park, M.H.; Jeong, S.; Lee, K.H.; Kim, J.Y. Evaluation of Error Inducing Factors in Unmanned Aerial Vehicle Mounted Detector to Measure Fugitive Methane from Solid Waste Landfill. Waste Manag. 2021, 124, 368-376. [CrossRef]

31. Sohoo, I.; Ritzkowski, M.; Kuchta, K. Influence of Moisture Content and Leachate Recirculation on Oxygen Consumption and Waste Stabilization in Post Aeration Phase of Landfill Operation. Sci. Total Environ. 2021, 773, 145584. [CrossRef]

32. Propp, V.R.; De Silva, A.O.; Spencer, C.; Brown, S.J.; Catingan, S.D.; Smith, J.E.; Roy, J.W. Organic Contaminants of Eemerging Concern in Leachate of Historic Municipal Landfills. Environ. Pollut. 2021, 276, 116474. [CrossRef]

33. Peng, W.; Pivato, A.; Cerminara, G.; Garbo, F.; Raga, R. Denitrifcation of Mature Landfill Leachate with High Nitrite in Simulated Landfill Columns Packed with Solid Digestate from Organic Fraction of Municipal Solid Waste. Waste Biomass Valori. 2020, 11, 411-421. [CrossRef]

34. Cheah, Y.K.; Vidal-Antich, C.; Dosta, J.; Mata-Álvarez, J. Volatile Fatty Acid Production from Mesophilic Acidogenic Fermentation of Organic Fraction of Municipal Solid Waste and Food Waste under Acidic and Alkaline pH. Environ. Sci. Pollut. Res. 2019, 26, 35509-35522. [CrossRef] [PubMed]

35. Deepesh, V.; Verma, V.K.; Suma, K.; Ajay, S.; Gnanavelu, A.; Madhusudanan, M. Evaluation of an organic soil amendment generated from municipal solid waste seeded with activated sewage sludge. J. Mater. Cycles Waste Manag. 2016, 18 , $273-286$. [CrossRef]

36. Cudjoe, D.; Acquah, P.M. Environmental Impact Analysis of Municipal Solid Waste Incineration in African Countries. Chemosphere 2020, 265, 129186. [CrossRef] [PubMed]

37. Ogawa, N.; Amano, T.; Nagai, Y.; Hagiwara, K.; Honda, T.; Koike, Y.Y. Water Repellents for the Leaching Control of Heavy Metals in Municipal Solid Waste Incineration Fly Ash. Waste Manag. 2021, 124, 154-159. [CrossRef] [PubMed]

38. Kremser, K.; Thallner, S.; Strbik, D.; Spiess, S.; Kucera, J.; Vaculovic, T.; Vsiansky, D.; Haberbauer, M.; Mandl, M.; Guebitz, G.M. Leachability of Metals from Waste Incineration Residues by Iron- and Sulfur-oxidizing Bacteria. J. Environ. Manag. 2021, 280, 111734. [CrossRef]

39. Munir, M.T.; Mansouri, S.S.; Udugama, I.A.; Baroutian, S.; Gernaey, K.V.; Young, B.R. Resource Recovery from Organic Solid Waste using Hydrothermal Processing: Opportunities and Challenges. Renew. Sustain. Energy Rev. 2018, 96, 64-75. [CrossRef]

40. Cesaro, A. The Valorization of the Anaerobic Digestate from the Organic Fractions of Municipal Solid Waste: Challenges and Perspectives. J. Environ. Manag. 2021, 280, 111742. [CrossRef]

41. Zamri, M.F.M.A.; Hasmady, S.; Akhiar, A.; Ideris, F.; Shamsuddin, A.H.; Mofijur, M.; Rizwanul Fattah, I.M.; Mahlia, T.M.I. A Comprehensive Review on Anaerobic Digestion of Organic Fraction of Municipal Solid Waste. Renew. Sustain. Energy Rev. 2021, 137, 110637. [CrossRef]

42. Kainthola, J.; Kalamdhad, A.S.; Goud, V.V. Enhanced Methane Production from Anaerobic co-digestion of Rice Straw and Hydrilla Verticillata and its Kinetic Analysis. Biomass Bioenergy 2019, 125, 8-16. [CrossRef]

43. Ryue, J.; Lin, L.; Liu, Y.; Lu, W.J.; McCartney, D.; Dhar, B.R. Comparative Effects of GAC Addition on Methane Productivity and Microbial Community in Mesophilic and Thermophilic Anaerobic Digestion of Food Waste. Biochem. Eng. J. 2019, $146,79-87$. [CrossRef]

44. Zhang, L.G.; Duan, H.R.; Ye, L.; Liu, L.; Batstone, D.J.; Yuan, Z.G. Increasing Capacity of an Anaerobic Sludge Digester through FNA Pre-treatment of Thickened Waste Activated Sludge. Water Res. 2019, 149, 406-413. [CrossRef] [PubMed]

45. Hao, Y.; Wang, Y.Y.; Ma, C.X.; White, J.C.; Zhao, Z.Q.; Duan, C.; Zhang, Y.L.; Adeel, M.; Rui, Y.K.; Li, G.X.; et al. Carbon Nanomaterials Induce Residue Degradation and Increase Methane Production from Livestock Manure in an Anaerobic Digestion System. J. Clean. Prod. 2019, 240, 118257. [CrossRef]

46. Bucker, F.; Marder, M.; Peiter, M.R.; Lehn, D.N.; Esquerdo, V.M.; de Almeida Pinto, L.A.; Konrad, O. Fish Waste: An Efficient Alternative to Biogas and Methane Production in an Anaerobic Mono-digestion System. Renew. Energy 2020, 147, 798-805. [CrossRef]

47. Syafiuddin, A.; Boopathy, R. Role of Anaerobic Sludge Digestion in Handling Antibiotic Resistant Bacteria and Antibiotic Resistance Genes-A review. Bioresour. Technol. 2021, 330, 124970. [CrossRef]

48. Andriamanohiarisoamananaa, F.J.; Iharaa, I.; Yoshidaa, G.; Umetsub, K. Tackling antibiotic inhibition in anaerobic digestion: The roles of $\mathrm{Fe}^{3+}$ and $\mathrm{Fe}_{3} \mathrm{O}_{4}$ on process performance and volatile fatty acids utilization pattern. Bioresour. Technol. Rep. 2020, 11,110460 .

49. Azizi, S.M.M.; Hai, F.I.; Lu, W.J.; Al-Mamun, A.; Dhar, B.R. A Review of Mechanisms Underlying the Impacts of (nano)Microplastics on Anaerobic Digestion. Bioresour. Technol. 2021, 329, 124894.

50. Huang, Y.; Li, D.Y.; Wang, L.; Yong, C.; Sun, E.H.; Jin, H.M.; Huang, H.Y. Decreased Enzyme Activities, Ammonification Rate and Ammonifiers Contribute to Higher Nitrogen Retention in Hyperthermophilic Pretreatment Composting. Bioresour. Technol. 2019, 272, 521-528. [CrossRef]

51. Cao, Y.; Wang, J.D.; Huang, H.Y.; Sun, E.H.; Butterly, C.; Xu, Y.D.; He, H.; Zhang, J.; Chang, Z.Z. Spectroscopic Evidence for Hyperthermophilic Pretreatment Intensifying Humification During Pig Manure and Rice Straw Composting. Bioresour. Technol. 2019, 294, 122131. [CrossRef]

52. Ren, X.N.; Wang, Q.; Zhang, Y.; Awasthi, M.K.; He, Y.F.; Li, R.H.; Zhang, Z.Q. Improvement of Humification and Mechanism of Nitrogen Transformation during Pig Manure Composting with Black Tourmaline. Bioresour. Technol. 2020, 307, 123236. [CrossRef] [PubMed] 
53. Moreno, J.; López-González, J.A.; Arcos-Nievas, M.A.; Suárez-Estrella, F.; Jurado, M.M.; Estrella-González, M.J.; López, M.J. Revisiting the Succession of Microbial Populations throughout Composting: A Matter of Thermotolerance. Sci. Total Environ. 2021, 773, 145587. [CrossRef] [PubMed]

54. Costa, L.A.M.; Costa, M.S.S.M.; Damaceno, F.M.; Chiarelotto, M.; Bofinger, J.; Gazzola, W. Bioaugmentation as A Strategy to Improve the Compost Quality in the Composting Process of Agro-industrial Wastes. Environ. Technol. Innov. 2021, $22,101478$. [CrossRef]

55. Lin, C.; Cheruiyot, N.K.; Hoang, H.G.; Le, T.H.; Tran, H.T.; Bui, X.T. Benzophenone Biodegradation and Characterization of Malodorous Gas Emissions During Co-composting of Food Waste with Sawdust and Mature Compost. Environ. Technol. Innov. 2021, 21, 101351. [CrossRef]

56. Panigrahi, S.; Dubey, B.K. A Critical Review on Operating Parameters and Strategies to Improve the Biogas Yield from Anaerobic Digestion of Organic Fraction of Municipal Solid Waste. Renew. Energy 2019, 143, 779-797. [CrossRef]

57. Yu, Z.; Tang, J.; Liao, H.P.; Liu, X.M.; Zhou, P.X.; Chen, Z.; Rensing, C.; Zhou, S.G. The Distinctive Microbial Community Improves Composting Efficiency in a full-scale Hyperthermophilic Composting Plant. Bioresour. Technol. 2018, 265, 146-154. [CrossRef]

58. Afonso, S.; Arrobas, M.; Pereira, E.L.; Rodrigues, M.A. Recycling Nutrient-rich Hop Leaves by Composting with Wheat Straw and Farmyard Manure in Suitable Mixtures. J. Environ. Manag. 2021, 284, 112105. [CrossRef]

59. Kanazawa, S.; Ishikawa, Y.; Tomita-Yokotani, K.; Hashimoto, H.; Kitaya, Y.; Yamashita, M.; Nagatomo, M.; Oshima, T.; Wada, H.; Space Agriculture Task Force. Space Agriculture for Habitation on Mars with Hyper-thermophilic Aerobic Composting Bacteria. Adv. Space Res. 2008, 41, 696-700. [CrossRef]

60. Liao, H.P.; Chen, Z.; Yu, Z.; Lu, X.M.; Wang, Y.; Zhou, S.G. Development of Hyperthermophilic Aerobic Composting and its Engineering Application in Organic Solid Wastes. J. Fujian Agric. For. Univ. Nat. Sci. Ed. 2017, 46, 439-444. (In Chinese)

61. Xue, Z.J.; Zhou, G.Y.; Yu, X.F.; Wang, H.C.; Wang, Y.Y.; Zheng, D.W.; Jia, F.X.; Huang, Y.; Wang, S.Y.; Peng, Y.Z. Ultra High Temperature Aerobic Composting Process in Treating Municipal Sludge. China Environ. Sci. 2017, 37, 3399-3406. (In Chinese)

62. Cui, P.; Chen, Z.; Zhao, Q.; Yu, Z.; Yi, Z.G.; Liao, H.P.; Zhou, S.G. Hyperthermophilic Composting Significantly Decreases $\mathrm{N}_{2} \mathrm{O}$ Emissions by Regulating $\mathrm{N}_{2} \mathrm{O}$-related Functional Genes. Bioresour. Technol. 2019, 272, 433-441. [CrossRef] [PubMed]

63. Research and Application of Ultra-High Temperature Aerobic Fermentation Technology for Sludge Treatment. Available online: http:/ / www.water8848.com/news/201911/01/121574.html (accessed on 6 May 2020). (In Chinese).

64. Oshima, T.; Moriya, T. A Preliminary Analysis of Microbial and Biochemical Properties of High-temperature Compost. Ann. N. Y. Acad. Sci. 2008, 1125, 338-344. [CrossRef] [PubMed]

65. Gurusamy, N.N.; Puffer, N.; Jongh, C.; Gil, C.R.; Aspray, T.J. Effect of Initial Moisture Content and Sample Storage Duration on Compost Stability Using the ORG0020 Dynamic Respiration Test. Waste Manag. 2021, 125, 215-219. [CrossRef] [PubMed]

66. Graça, J.; Murphy, B.; Pentlavalli, P.; Allen, C.C.R.; Bird, E.; Gaffney, M.; Duggan, T.; Kelleher, B. Bacterium Consortium Drives Compost Stability and Degradation of Organic Contaminants in in-vessel Composting Process of the Mechanically Separated Organic Fraction of Municipal Solid Waste (MS-OFMSW). Bioresour. Technol. Rep. 2021, 13, 100621. [CrossRef]

67. Photographs. Available online: https:/ / so.youku.com/ (accessed on 1 May 2020).

68. Chen, Z.; Zhao, W.Q.; Xing, R.Z.; Xie, S.J.; Yang, X.G.; Cui, P.; Lu, J.; Liao, H.P.; Yu, Z.; Wang, S.H.; et al. Enhanced in situ Biodegradation of Microplastics in Sewage Sludge Using Hyperthermophilic Composting Technology. J. Hazard. Mater. 2020, 384, 121271. [CrossRef]

69. Tang, J.; Zhuang, L.; Yu, Z.; Liu, X.M.; Wang, Y.Q.; Wen, P.; Zhou, S.G. Insight into Complexation of Cu(II) to Hyperthermophilic compost-derived Humic Acids by EEM-PARAFAC Combined with Heterospectral Two Dimensional Correlation Analyses. Sci. Total Environ. 2019, 656, 29-38. [CrossRef]

70. Chen, Z.; Xing, R.Z.; Yang, X.G.; Zhao, Z.Q.; Liao, H.P.; Zhou, S.G. Enhanced in situ Pb(II) Passivation by Biotransformation into Chloropyromorphite During Sludge Composting. J. Hazard. Mater. 2021, 408, 124973. [CrossRef]

71. Liao, H.P.; Zhao, Q.; Cui, P.; Chen, Z.; Yu, Z.; Geisen, S.; Friman, V.P.; Zhou, S.G. Efficient Reduction of Antibiotic Residues and Associated Resistance Genes in Tylosin Antibiotic Fermentation Waste using Hyperthermophilic Composting. Environ. Int. 2019, 133, 105203. [CrossRef]

72. Liao, H.P.; Lu, X.M.; Rensing, C.; Friman, V.P.; Geisen, S.; Chen, Z.; Yu, Z.; Wei, Z.; Zhou, S.G.; Zhu, Y.G. Hyperthermophilic Composting Accelerates the Removal of Antibiotic Resistance Genes and Mobile Genetic Elements in Sewage Sludge. Environ. Sci. Technol. 2018, 52, 266-276. [CrossRef] 